\title{
Comentário à sentença de Mons. Felipe Heredia Esteban de 4 de junho de 2018
}

Commentary on the sentence of Msgr. Felipe Heredia Esteban of 4 June 2018

Vincenzo Fasano ${ }^{1}$

\section{Português}

A íntima comunidade de vida e amor conjugal, fundada pelo Criador e dotada de leis próprias, é instituída por meio da aliança matrimonial, ou seja pelo irrevogável consentimento pessoal. Deste modo, por meio de um ato humano com o qual os cônjuges mutuamente se dão e recebem um ao outro, nasce uma instituição também diante da sociedade e confirmada por lei divina. Em vista do bem tanto dos esposos como da prole e da sociedade, este sagrado vínculo não está ao arbítrio da vontade humana, porque o próprio Deus é o autor do matrimônio, o qual possui diversos bens e fins (cf. Concilium Vaticanum II, Const. past. Gaudium et spes, en Acta Apostolicae Sedis 58 [1966], p. 1067, n. 48). O matrimônio origina-se do consentimento entre pessoas juricamente hábeis e legitimamente manifestado. $\mathrm{O}$ consentimento é o ato humano da vontade pelo qual o homem e a mulher, por pacto irrevogável, se entregam e recebem mutuamente, a fim de constituírem o matrimônio (cf. can. 1057 C.I.C.). De fato, Santo Tomás de Aquino recorda que: «Das ações feitas pelo homem só se chamam propriamente humanas as que lhe são próprias, enquanto homem. Ora, este difere das criaturas irracionais, por ser senhor dos seus atos. Por onde, chamam-se propriamente ações humanas só aquelas de que o homem é senhor. Ora, senhor das suas ações o homem o é pela

Professor na Faculdade de Direito Canônico da Pontificia Università S. Tommaso D’Aquino in Urbe, Advogado do Tribunal Apostólico da Rota Romana, Postulador para as Causas dos Santos e advogado nos Tribunais do Estado da Cidade do Vaticano (Juíz único, Tribunal, Corte de Apelo e Cassação). 
razão e pela vontade, sendo por isso o livre arbítrio chamado de «faculdade da vontade e da razão». Portanto, chamam-se ações propriamente humanas as procedentes da vontade deliberada; e se há outras que convêm ao homem, essas podem, por certo, chamar-se ações do homem, mas não propriamente humanas, pois não procedem dele como tal. Ora, é manifesto que todas as ações procedentes de uma potência são por esta causadas, quanto à essência do objeto mesmo delas. E como o objeto da vontade é o fim e o bem, é necessário que tendam todas as ações humanas para um fim» (cf. Summa Theologica, IIIae, q. 1, a. 1, Resp., en Santo Tomás de Aquino, La somma teologica, Bologna, 1984, p. 39) [Sentença, § 3].

O cân. 1095 do Código de Direito Canônico prevê que «São incapazes de contrair matrimónio: $1 .^{\circ}$ os que carecem do uso suficiente da razão; $2{ }^{\circ}$ os que sofrem de defeito grave de discrição do juízo acerca dos direitos e deveres essenciais do matrimônio, que se devem dar e receber mutuamente; $3^{\circ}$ os que por causas de natureza psíquica não podem assumir as obrigações essenciais do matrimônio». Para que o juiz atinja a certeza moral prevista no cân. $1608, \S 1$, C.I.C., entre os vários meios de prova disponíveis, um papel fundamental pertence ao perito, cuja tarefa é detectar a condição psíquica das partes no momento do casamento, através das teorias e metodologias típicas da disciplina própria, e de acordo com uma antropologia cristã saudável [Sentença, §§ 4-7].

Mesmo após a declaração de nulidade do matrimónio canônico, se uma das partes é um diácono permanente, é necessário lembrar na sentença que o homem não pode ter acesso a um novo casamento, porque o impedimento da ordem sagrada repousa sobre ele [Sentença, $\S$ $14]$.

\section{Italiano}

L'intima comunità di vita e d'amore coniugale, fondata dal Creatore e strutturata con leggi proprie, è stabilita dall'alleanza dei coniugi, cioè dall'irrevocabile consenso personale. È dall'atto umano col quale i coniugi mutuamente si danno e si ricevono, che nasce, anche davanti alla società, l'istituzione del matrimonio, che ha stabilità per 
ordinamento divino. In vista del bene dei coniugi, della prole e anche della società, questo legame sacro non dipende dall'arbitrio dell'uomo, perché è Dio stesso l'autore del matrimonio, dotato di molteplici valori e fini (cf. Concilium Vaticanum II, Const. past. Gaudium et spes, in Acta Apostolicae Sedis 58 [1966], p. 1067, n. 48). L'atto che costituisce il matrimonio è il consenso delle parti manifestato legittimamente tra persone giuridicamente abili. Esso è un atto umano della volontà con cui l'uomo e la donna, con patto irrevocabile, danno e accettano reciprocamente se stessi per costituire il matrimonio (cf. can. 1057 C.I.C.). San Tommaso d'Aquino ricorda infatti che: «Tra le azioni che l'uomo compie sono dette umane in senso stretto soltanto quelle compiute dall'uomo in quanto uomo. Ora, l'uomo si distingue dalle altre creature non razionali perché è padrone dei propri atti. Quindi, in senso stretto, si dicono umane le sole azioni di cui l'uomo ha la padronanza. D'altra parte l'uomo è padrone dei suoi atti mediante la ragione e la volontà: infatti si dice che il libero arbitrio è «una facoltà della volontà e della ragione». Quindi propriamente sono denominate umane le azioni che procedono da una volontà deliberata. Le altre azioni invece che vengono attribuite all'uomo potranno essere dette azioni dell'uomo, ma non azioni umane in senso proprio, non appartenendo esse all'uomo in quanto uomo. Ora, tutti gli atti che procedono da una data facoltà ne derivano secondo la ragione formale del suo oggetto. Ma l'oggetto della volontà è il fine e il bene. Quindi è necessario che tutte le azioni umane siano per un fine» (cf. Summa Theologica, I-IIae, q. 1, a. 1, Resp., in San Tommaso d'Aquino, La somma teologica, Bologna, 1984, p. 39) [Sentenza, § 3].

Il can. 1095 del Codice di diritto canonico prevede che «Sono incapaci a contrarre matrimonio: 1) coloro che mancano di sufficiente uso di ragione; 2) coloro che difettano gravemente di discrezione di giudizio circa i diritti e i doveri matrimoniali essenziali da dare e accettare reciprocamente; 3 ) coloro che per cause di natura psichica, non possono assumere gli obblighi essenziali del matrimonio». Affinché il giudice possa pervenire alla certezza morale prevista dal can. $1608, \S 1$, C.I.C., fra $\mathrm{i}$ diversi mezzi di prova a sua disposizione, un ruolo fondamentale spetta al perito, il cui compito è di rilevare la condizione psichica delle parti al momento della celebrazione del matrimonio, 
tramite le teorie e le metodologie tipiche della propria disciplina, e secondo una sana antropologia cristiana [Sentenza, §§ 4-7].

Anche dopo la dichiarazione di nullità del matrimonio canonico, qualora una delle parti sia un diacono permanente, è necessario rammentare nella sentenza l'uomo non può accedere a nuove nozze perché su di lui grava l'impedimento di ordine sacro [Sentenza, § 14].

\section{Français}

La communauté profonde de vie et d'amour que forme le couple a été fondée et dotée de ses lois propres par le Créateur; elle est établie sur l'alliance des conjoints, c'est-à-dire sur leur consentement personnel irrévocable. Une institution, que la loi divine confirme, naît ainsi, au regard même de la société, de l'acte humain par lequel les époux se donnent et se reçoivent mutuellement. En vue du bien des époux, des enfants et aussi de la société, ce lien sacré échappe à la fantaisie de l'homme, car Dieu lui-même est l'auteur du mariage qui possède en propre des valeurs et des fins diverses (cf. Concilium Vaticanum II, Const. past. Gaudium et spes, en Acta Apostolicae Sedis 58 [1966], p. 1067, n. 48). C'est le consentement des parties légitimement manifesté entre personnes juridiquement capables qui fait le mariage. Il est l'acte humaine de la volonté par lequel un homme et une femme se donnent et se reçoivent mutuellement par une alliance irrévocable pour constituer le mariage (cf. can. 1057 C.I.C.). Saint Thomas d'Aquin rappelle en effet que: «Parmi les actions accomplies par l'homme, celles-là seules sont appelées proprement "humaines" qui appartiennent en propre à l'homme selon qu'il est homme. Et l'homme diffère des créatures privées de raison en ce qu'il est maître de ses actes. D'où il suit qu'il faut appeler proprement humaines les seules actions dont l'homme est le maître. Mais c'est par sa raison et sa volonté que l'homme est le maître de ses actes, ce qui fait que le libre arbitre est appelé "une faculté de la volonté et de la raison". Il n'y a donc de proprement humaines que les actions qui procèdent d'une volonté délibérée. S'il est d'autres actions qui conviennent à l'homme, on pourra les appeler des actions de l'homme, mais non pas des actions proprement humaines, puisqu'elles ne procèdent pas de l'homme en tant qu'homme. Or, il est manifeste que 
toute action procédant d'une puissance est produite par cette puissance selon le caractère de son objet et l'objet de la volonté c'est la fin et le bien. Il est donc nécessaire que toutes les actions humaines soient faites pour une fin» (cf. Summa Theologica, I-IIae, q. 1, a. 1, Resp., en Saint Thomas d'Aquin, La somma teologica, Bologna, 1984, p. 39) [Sentence, $\S 3]$.

Le can. 1095 du Code de droit canonique prévoit que «Sont incapables de contracter mariage les personnes: $1^{\circ}$ qui n'ont pas l'usage suffisant de la raison; $2^{\circ}$ qui souffrent d'un grave défaut de discernement concernant les droits et les devoirs essentiels du mariage à donner et à recevoir mutuellement; $3^{\circ}$ qui pour des causes de nature psychique ne peuvent assumer les obligations essentielles du mariage». Pour que le juge atteigne la certitude morale prévue au can. 1608, $\S 1$, C.I.C., parmi les divers moyens de preuve à sa disposition, un rôle fondamental incombe à l'expert, chargé de détecter l'état psychique des parties au moment de la célébration du mariage, à travers les théories et les méthodologies typiques de leur discipline, et selon une anthropologie chrétienne saine [Sentence, $\S \S 4-7]$.

Même après la déclaration de nullité du mariage canonique, si l'une des parties est un diacre permanent, il est nécessaire de rappeler dans la sentence que l'homme ne peut accéder à un nouveau mariage parce que l'empêchement de l'ordre sacré lui incombe [Sentence, § 14].

\section{Español}

Fundada por el Creador y en posesión de sus propias leyes, la íntima comunidad conyugal de vida y amor se establece sobre la alianza de los cónyuges, es decir, sobre su consentimiento personal e irrevocable. Así, del acto humano por el cual los esposos se dan y se reciben mutuamente, nace, aun ante la sociedad, una institución confirmada por la ley divina. Este vínculo sagrado, en atención al bien tanto de los esposos y de la prole como de la sociedad, no depende de la decisión humana pues es el mismo Dios el autor del matrimonio y le ha dotado de bienes y fines varios (cf. Concilium Vaticanum II, Const. past. Gaudium et spes, en Acta Apostolicae Sedis 58 [1966], p. 1067, n. 48). El matrimonio lo produce el consentimiento de las partes legítimamente 
manifestado entre personas jurídicamente capaces, tal consentimiento es el acto humano de la voluntad, por el cual el varón y la mujer se entregan y aceptan mutuamente en alianza irrevocable para constituir el matrimonio (cf. can. 1057 C.I.C.). De hecho, Santo Tomás de Aquino recuerda que: «De entre las acciones que el hombre realiza, solo pueden considerarse propiamente humanas aquellas que son propias del hombre en cuanto que es hombre. El hombre se diferencia de las criaturas irracionales en que es dueño de sus actos. Por eso, solo aquellas acciones de las que el hombre es dueño pueden llamarse propiamente humanas. El hombre es dueño de sus actos mediante la razón y la voluntad; así, se define el libre albedrío como facultad de la voluntad y de la razón. Llamamos, por tanto, acciones propiamente humanas a las que proceden de una voluntad deliberada. Las demás acciones que se atribuyen al hombre pueden llamarse del hombre, pero no propiamente humanas, pues no pertenecen al hombre en cuanto que es hombre. Ahora bien, todas las acciones que proceden de una potencia son causadas por ella en razón de su objeto. Pero el objeto de la voluntad es el bien y el fin. Luego es necesario que todas las acciones humanas sean por un fin» (cf. Summa Theologica, I-IIae, q. 1, a. 1, Resp., en Santo Tomás de Aquino, La somma teologica, Bologna, 1984, p. 39) [Sentencia, § 3].

El can. 1095 del Código de Derecho Canónico establece que « Son incapaces de contraer matrimonio: 1) quienes carecen de suficiente uso de razón; 2) quienes tienen un grave defecto de discreción de juicio acerca de los derechos y deberes esenciales del matrimonio que mutuamente se han de dar y aceptar; 3) quienes no pueden asumir las obligaciones esenciales del matrimonio por causas de naturaleza psíquica». Para que el juez alcance la certeza moral prevista en el can. $1608, \S 1$, C.I.C., entre los diversos medios de prueba a su disposición, un papel fundamental corresponde al experto, cuya tarea es detectar la condición psíquica de las partes en el momento del matrimonio, a través de las teorías y metodologías típicas de su propia disciplina, y de acuerdo con una sana antropología cristiana [Sentencia, §§ 4-7].

Incluso después de la declaración de nulidad del matrimonio canónico, si una de las partes es un diácono permanente, es necesario recordar en la sentencia que el hombre no puede acceder a un nuevo 
matrimonio porque el impedimento del orden sacro recae sobre él [Sentencia, § 14].

\section{English}

The intimate partnership of married life and love has been established by the Creator and qualified by His laws, and is rooted in the conjugal covenant of irrevocable personal consent. Hence by that human act whereby spouses mutually bestow and accept each other a relationship arises which by divine will and in the eyes of society too is a lasting one. For the good of the spouses and their off-springs as well as of society, the existence of the sacred bond no longer depends on human decisions alone. For, God Himself is the author of matrimony, endowed as it is with various benefits and purposes (cf. Concilium Vaticanum II, Const. past. Gaudium et spes, in Acta Apostolicae Sedis 58 [1966], p. 1067, n. 48). A marriage is brought into being by the lawfully manifested consent of persons who are legally capable. This consent is an human act of will by which a man and a woman by an irrevocable covenant mutually give and accept one another for the purpose of establishing a marriage (cf. can. 1057 C.I.C.). In fact, St. Thomas Aquinas recalls that: «Of actions done by man those alone are properly called "human", which are proper to man as man. Now man differs from irrational animals in this, that he is master of his actions. Wherefore those actions alone are properly called human, of which man is master. Now man is master of his actions through his reason and will; whence, too, the free-will is defined as "the faculty and will of reason". Therefore those actions are properly called human which proceed from a deliberate will. And if any other actions are found in man, they can be called actions "of a man", but not properly "human" actions, since they are not proper to man as man. Now it is clear that whatever actions proceed from a power, are caused by that power in accordance with the nature of its object. But the object of the will is the end and the good. Therefore all human actions must be for an end» (cf. Summa Theologica, I-IIae, q. 1, a. 1, Resp., St. Thomas Aquinas, La somma teologica, Bologna, 1984, p. 39) [Sentence, § 3]. 
The can. 1095 of the Code of Canon Law provides that «The following are incapable of contracting marriage: $1^{\circ}$ those who lack sufficient use of reason; $2^{\circ}$ those who suffer from a grave lack of discretionary judgement concerning the essential matrimonial rights and obligations to be mutually given and accepted; $3^{\circ}$ those who, because of causes of a psychological nature, are unable to assume the essential obligations of marriage». So that the judge can reach the moral certainty provided for in can. $1608, \S 1$, C.I.C., among the various means of proof at his disposal, a fundamental role pertains to the expert, whose task is to detect the psychic condition of the parties at the time of the marriage, through the theories and methodologies typical of their own discipline, and according to a healthy Christian anthropology [Sentence, §§ 4-7].

Even after the declaration of nullity of the canonical marriage, if one of the parties is a permanent deacon, it is necessary to remember in the sentence the man cannot access a new marriage because the impediment of sacred order rests on him [Sentence, $\S 14]$. 